\title{
Saluran Pemasaran dan Nilai Tambah Kopi Robusta di Kecamatan Wonosalam Kabupaten Jombang, Jawa Timur
}

\author{
Mierza Widya Syahrani ${ }^{1}$, Mubarokah $^{2}$, Sri Tjondro Winarno ${ }^{3}$ \\ ${ }^{I}$ Fakultas Pertanian, UPN “Veteran” Jawa Timur, Jl. Raya Rungkut Madya, Gunung Anyar, Surabaya, 60294 \\ E-mail: mierzasyhrn@gmail.com \\ ${ }^{2}$ Fakultas Pertanian, UPN “Veteran” Jawa Timur, Jl. Raya Rungkut Madya, Gunung Anyar, Surabaya, 60294 \\ E-mail: mubarokah@upnjatim.ac.id \\ ${ }^{3}$ Fakultas Pertanian, UPN “Veteran” Jawa Timur, Jl. Raya Rungkut Madya, Gunung Anyar, Surabaya, 60294 \\ E-mail: sritjondro_w@upnjatim.ac.id
}

\begin{abstract}
The purpose of this study was to analyze the marketing channels and added value of Robusta coffee in Wonosalam District, Jombang Regency, East Java. The location determination is determined by purposive, where the location selection is made on a group of subjects based on the characteristics and characteristics of the production that have been previously known. Wonosalam Subdistrict, Jombang District, East Java To find out how many marketing channels there are and the amount of added value obtained from coffee processing, the Hayami method is used. The results of the study indicate that there are five marketing channels in Wonosalam District, Jombang Regency. While the margin obtained from the analysis of the added value of pure powder is $R p$. 198,000, - from raw materials, the amount of margin will be distributed to production factors, consisting of $38.83 \%$ for labor income and $22.72 \%$ for other input contributions, and for a profit of $43.43 \%$.
\end{abstract}

Keywords—: Rabusta; Marketing Channels; Value Added.

\section{PENDAhUluaN}

Pengembangan Kawasan Agropolitan merupakan salah satu dokumen penting mengenai perencanaan makro yang komphrehensif dan suistainable sehingga dapat untuk menjamin sinergitas dalam rangka melaksanakan Pengembangan Kawasan Agropolitan (PKA). (Erna Rustiadi, 2009)

Pembangunan agribisnis yang dipengaruhi oleh kondisi lingkungan fisik, menjadikan agribisnis tidak bertentangan dengan otonomi daerah. Diharapkan agribisnis dapat berkembang dengan lebih baik dengan adanya otonomi daerah. Hal ini disebabkan dengan otonomi daerah maka setiap daerah mempunyai kewenangan walaupun tidak secara penuh untuk mengembangkannya akan tetapi bisa melakukan terobosan pembangunan agribisnis ini sesuai dengan spesifikasi komoditas yang ada di daerahnya. Sektor pertanian salah satunya yaitu sub sektor perkebunan mempunyai potensi besar dan peranan yang cukup penting dalam kegiatan perekonomian di Indonesia. Sektor perkebunan khususnya kopi merupakan salah satu komoditas ekspor Indonesia mempunyai peran penting dengan adanya peluang ekspor yang semakin terbuka dan besarnya peluang pasar kopi di dalam negeri (BPS 2019). Produksi kopi Indonesia mengalami peningkatan setiap tahunnya. Tahun 2019 jumlah produksi kopi mencapai 760963 ton (Direktorat jenderal Perkebunan 2019).

Perkebunan kopi di Indonesia menurut pengusahaannya yaitu perkebunan rakyat (PR) merupakan penghasil utama kopi Indonesia. Produksi kopi perkebunan rakyat pada tahun 2019 mencapai 685,79 ribu ton atau mencapai 96,6\% dari jumlah produksi kopi di Indonesia (BPS 2019). Sentra produksi utama kopi di Indonesia terdapat di lima provinsi sentra, produksi kopi tersebut diantaranya terdapat di Sumatra Selatan, Lampung, Sumatra Utara, Aceh dan Jawa timur.

Terdapat empat jenis kelompok kopi yang banyak dikenal di Indonesia yaitu, kopi arabika, kopi robusta, kopi liberika dan kopi ekselsa. Mayoritas petani kopi di Indonesia menanam jenis kopi arabika dan kopi robusta, kopi tersebut memiliki nilai ekonomis dan banyak diperdagangkan karena memiliki kualitas dan cita rasa tinggi. Jenis kopi liberika dan kopi ekselsa tidak banyak ditanam karena kurang memiliki nilai ekonomis dan belum banyak diperdagangkan (Rahardjo 2012).

Kabupaten Jombang merupakan salah satu daerah penghasil kopi excelsa terbesar yang terdapat di Jawa Timur. Menurut SK Bupati Jombang No.188.4.45/189/415.10.10/2010 tentang penetapan lokasi dan komoditas unggulan kawasan agropolitan telah ditetapkan 15 komoditas unggulan, salah satunya adalah komoditas Kopi Wonosalam. Terdapat tiga jenis kopi yang banyak tumbuh di Kecamatan Wonosalam antara lain robusta, excelsa dan arabika. Kopi robusta dapat ditanam di dataran dengan ketinggian 400-800 m dpl. Jenis kopi robusta mempunyai kelebihan tahan terhadap penyakit karat daun, penyakit yang sering menyerang tanaman kopi pada lahan dataran rendah (Hamdan and Sontani 2018). 
Website : http://agritek.unmermadiun.ac.id/index.php/agritek

Pemasaran merupakan kegiatan distribusi yang mempunyai fungsi membawa atau menyampaikan barang dari produsen ke konsumen (Hanafie 2010). Menurut (Kotler 2011), pemasaran merupakan suatu proses sosial dan manajerial dimana terdapat individu dan kelompok mendapatkan apa yang mereka butuhkan dan inginkan dengan menciptakan, menawarkan dan mempertukarkan produk yang bernilai dengan individu dan kelompok lainnya. Selanjutnya (Kotler and Amstrong 2006), definisi saluran pemasaran atau disebut juga saluran distribusi adalah sekelompok organisasi yang saling membantu menyediakan produk dan atau jasa untuk digunakan oleh konsumen atau pengguna bisnis. Saluran pemasaran adalah semua semua pelaku bisnis yang berpartisipasi dalam mendistribusikan produk dari produsen ke konsumen akhir. Jenis saluran pemasaran menurut (Sumarwan n.d.), yaitu : Saluran tingkat nol (saluran pemasaran langsung), mendistribusikan produk dari produsen ke konsumen akhir tanpa pelaku bisnis perantara. Saluran tingkat pertama, terdiri dari dua pelaku bisnis yaitu produsen dan pengecer. Terdapat satu perantara antara produsen dan konsumen. Saluran pemasaran tingkat dua, terdapat dua pelaku bisnis perantara antara produsen dan konsumen. Pelaku perantara pertama biasa nya disebut sebagai distributor utama atau pedagang besar. Pelaku perantara kedua yaitu para pengecer seperti toko, warung, swalayan, mini market atau supermarket. Saluran pemasaran tingkat tiga, terdiri dari produsen dan tiga pelaku perantara antara produsen ke konsumen. Produk disalurkan ke distributor atau pedagang besar, selanjutnya disalurkan ke subdistributir atau agen atau grosir dan dilanjutkan ke pengecer. yang aktif terdiri dari petani produsen, pedagang pengumpul, pedagang besar,pengecer dan konsumen.

Analisis nilai tambah bermanfaat untuk melihat seberapa jauh dampak nilai tambah terhadap usaha mengembangan kopi jenis robusta. Menurut (Pramasari and Hariyati 2018) dalam penelitiannya menyebutkan bahwa untuk menjadi produk agroindustri yang mampu bersaing maka perlu ditingkatkan nilainya, pengembangan nilai tambah berpotensi terciptanya suatu produk unggulan. Petani dapat menciptakan nilai tambah yang tinggi apabila kopi diproses menjadi kopi bubuk (Aklimawati 2017). Konsep nilai tambah adalah perubahan nilai yang terjadi karena adanya perlakuan terhadap suatu input pada suatu proses produksi. Nilai tambah dihitung secara kuantitatif dari peningkatan produktivitas. Produk pertanian yang mudah rusak dan bulky membutuhkan perlakuan yang tepat untuk meningkatkan harga produk pertanian (Marimin and Maghfiroh 2010).

Analisis nilai tambah menurut metode Hayami dilakukan dengan prosedur yang jelas. Informasi yang dihasilkan melalui metode Hayami pada subsistem agroindustri ini berupa (a) nilai tambah (RP), (b) rasio nilai tambah (\%), menunjukkan persentase imbalan tenaga kerja (\%), (c) balas jasa tenaga kerja (RP ), menunjukkan besar upah yang diterima oleh tenaga kerja langsung, (d) bagian tenaga kerja (\%), menunjukkan persentase imbalan tenaga kerja dari nilai tambah, (e) keuntungan (RP), menunjukkan bagian yang diterima pengusaha, (f) tingkat keuntungan (\%), menunjukkan persentase keuntungan terhadap nilai tambah. Karena ada tiga jenis produk yang diolah, maka jumlah tabel nilai tambah yang dihasilkan adalah sebanyak tiga tabel nilai tambah dengan metode Hayami.

Sektor perkebunan sampai saat ini merupakan salah satu penggerak utama perekonomian di provinsi Jawa Timur. Peranan sektor pertanian ditunjukkan dengan tingginya kontribusi sektor pertanian terhadap perekonomian di provinsi Jawa Timur. Kegiatan pascapanen merupakan bagian integral dari pengembangan agribisnis, yang dimulai dari aspek produksi bahan mentah sampai pemasaran produk akhir. Peran kegiatan pascapanen menjadi sangat penting, karena merupakan salah satu sub-sistem agribisnis yang mempunyai peluang besar dalam upaya meningkatkan nilai tambah produk agribisnis. Dibanding dengan produk segar, produk olahan mampu memberikan nilai tambah yang besar.

Tujuan penelitian ini untuk menganalisis saluran pemasaran dan nilai tambah dari kopi robusta di Kecamatan Wonosalam, Kabupaten Jombang, Jawa Timur.

\section{METODE PENELITIAN}

Penelitian ini menggunakan metode deskriptif analitis, penelitian deskriptif bertujuan untuk membuat gambaran mengenai situasi atau kejadian. Pemecahan masalah dilakukan dengan terlebih dahulu mengumpulkan data menggunakan teknik wawancara dan kuisioner. Data selanjutnya disusun dan dianalisis. Hasil akhirnya berupa gambaran lengkap permasalahan yang disajikan dalam bentuk tabel-tabel data dan variabel yang dianalisis baik secara kualitatif maupun kuantitatif (Nazir 2009).

Penentuan lokasi ditentukan dengan cara sengaja/Purposive, dimana pemilihan lokasi dilakukan atas sekelompok subyek yang didasarkan atas ciri-ciri dan sifat produksi yang telah diketahui sebelumnya. Kecamatan Wonosalam Kabupaten Jombang Jawa Timur Untuk mengetahui jumlah dari saluran pemasaran yang ada melakukan wanwancara dengan berbagi sumber serta pelaku kopi yang dapat dipercaya, sedangkan besarnya nilai tambah yang diperoleh dari pengolahan kopi, menggunakan metode perhitungan nilai tambah yang digunakan oleh (Hayami et al. 1987). a. Nilai tambah (RP) adalah selisih antara nilai output dengan bahan baku utamam dan sumbangan input lain. Rasio nilai tambah (\%) menunjukkan nilai tambah dari nilai produk; b. Pendapatan tenaga kerja (RP) menunjukkan upah yang diterima tenaga kerja untuk mengolah satu satuan bahan baku; c. Bagian tenaga kerja (\%) menunjukkan prosentase pendapatan tenaga kerja dari nilai tambah yang diperoleh; d. Pendapatan kotor (RP) menunjukkan bagian yang diterima perusahaan; e. Tingkat pendapatan kotor (\%) menunjukkan prosentase pendapatan kotor dari nilai produk; f. Margin (RP) menunjukkan besarnya kontribusi pemilik faktor-faktor produksi selain bahan baku yang digunakan dalam proses produksi; g. Prosentase pendapatan tenaga kerja terhadap margin $(\%)$; h. Prosentase sumbangan input tambahan terhadap margin $(\%)$. i. Prosentase keuntungan pengolahan terhadap margin $(\%)$.

Volume 22 Nomor 1 Maret 2021, AGRI-TEK | 48 


\section{III.HASIL DAN PEMBAHASAN}

Pemasaran dari petani hingga konsumen akhir memiliki pola saluran pemasaran yang berbeda, hal ini disebabkan oleh sifat dan jenis komoditas serta lingkungan asal komoditas tersebut. Secara umum, hasil produksi kopi robusta sebagian besar kopi dijual petani dalam bentuk kopi ose kepada tengkulak (50\%), kepada industri rumahan di daerah desa tempat petani (30\%) dan sisanya sebanyak $20 \%$ petani memilih menjual langsung ke unit pengolahan kopi sebagai pedagang pengepul desa dalam bentuk kopi gelondong serta memiliki lima pola saluran pemasaran yang meliputi,

Saluran pemasaran I termasuk ke jenis saluran pemasaran dua tingkat yang melibatkan dua lembaga pemasaran dalam memasarkan kopi robusta yaitu tengkulak dan industri rumahan. Sebagian besar petani kopi robusta di Kecamatan Wonosalam menggunakan saluran pertama, petani kopi menjual dalam bentuk kopi ose saat harga kopi sedang tinggi karena menurut petani kopi harga ditengkulak sesuaikan dengan harga pasar dan apabila dari harga yang diketahui oleh petani terdapat selisih petani dapat melakukan negosiasi. Saluran ini menjadi pilihan petani karena tidak perlu mengeluarkan biaya transportasi, tengkulak datang langsung mengambil hasil kopi ke rumah petani.

Saluran pemasaran II merupakan saluran pemasaran satu tingkat yaitu terdapat industri rumahan sebagai lembaga pemasaran. Saluran ini merupaka pilihan kedua yang banyak digunakan oleh petani dalam menjual hasil produksi kopi robustanya yang sudah diolah menjadi kopi ose. Petani memilih saluran ini karena harga yang diberikan industri rumahan dapat lebih tinggi dari harga yang diberikan oleh tengkulak terdapat selisih harga sebesar Rp500,- setiap kilonya. Pada saluran ke dua ini industri rumahan berperan sebagai pengolah kopi bubuk dan selanjutnya langsung dipasarkan ke konsumen akhir.

Saluran pemasaran III termasuk pada saluran pemasaran dua tingkat yaitu melibatkan dua lembaga pemasaran yang terdiri dari industri rumahan dan pedagang pengecer. Pada saluran ini petani menjual dalam bentuk kopi ose selanjutnya industri rumahan melakukan pengolahan dan menjualnya dalam bentuk berupa kopi robusta ose poles dan kopi bubuk murni. Pelaku industri rumahan menjual hasil olahan kopi ke pedagang pengecer yang terdapat di luar kota.

Saluran pemasaran IV merupakan saluran pemasaran dua tingkat yang melibatkan dua lembaga pemasaran yaitu pedagang pengepul desa dan pedagang besar. Pedagang pengepul desa yang dimaksud adalah unit pengolahan kopi (UPH) di tingkat desa sedangkan pedagang besar berada di tingkat kabupaten dan juga sebagai pabrik pengolahan kopi bubuk. Petani menjual hasil kopi ke pedagang pengepul dalam bentuk gelondong, selanjutnya UPH mengolah kopi gelondong menjadi kopi ose. Pola saluran pemasaran ini dipilih oleh petani karena keterbatasan peralatan dan modal. Pola ini juga masih dipilih karena terdapat kendala musim yang tidak menentu dimana musim hujan lebih panjang dari kemarau sehingga tidak terdapat panas matahari untuk menjemur hasil panen kopi. Kopi yang dijemur perlu dibawa ke daerah yang lebih rendah untuk mendapatkan panas matahari, hal tersebut menyebabkan pengeluaran petani lebih besar maka petani lebih memilih menjual langsung hasil panen kopi dalam bentuk gelondong.

Saluran pemasaran V merupakan saluran pemasaran tiga tingkat karena melibatkan tiga lembaga pemasaran yaitu terdapat tengkulak, pedagang pengepul desa dan pedagang besar sebagai pabrik pengolahan kopi bubuk. Petani menjual kopi dalam bentuk kopi ose ke pada tengkulak dengan cara tengkulak mendatangi langsung ke rumah petani, selanjutnya tengkulak menjual kopi dalam bentuk ose ke pedagang pengepul tingkat desa. Pedagang pengepul tingkat desa tidak melakukan fungsi pengolahan dan langsung menjual kopi ose dalam jumlah yang besar ke pedagang besar yang berada di kabupaten untuk diolah menjadi kopi bubuk. (Desiana, Rochdiani, and Pardani 2017), menyampaikan bahwa dalam pemasaran kopi robusta di Kalijaya Kecamatan Banjarsari Kabupaten Ciamis terdapat dua saluran pemasaran.

Analisis nilai tambah berguna untuk menguraikan proses produksi menurut sumbangan masing-masing faktor produksi. Dasar perhitungan metode analisis nilai tambah ini menggunakan perhitungan kg bahan baku kopi. Nilai tambah kopi dihitung berdasarkan jenis produk turunannya. Output (produk olahan agroindustri kopi) yang dihasilkan adalah bubuk kopi. Berikut adalah perhitungan nilai tambah kopi yang menghasilkan produk bubuk murni dengan metode Hayami.

Tabel 1. Biaya bahan baku dalam satu kali produksi (per minggu) petani kopi robusta di Kecamatan Wonosalam Kabupaten Jombang

\begin{tabular}{clcc}
\hline No & \multicolumn{1}{c}{ Uraian } & \multicolumn{2}{c}{ Kebutuhan } \\
\cline { 3 - 4 } & & Minggu & Bulan \\
\hline 1 & $\begin{array}{l}\text { Frekuensi Pembuatan } \\
\text { kopi bubuk }\end{array}$ & \multicolumn{1}{c}{1} & 12 \\
2 & $\begin{array}{l}\text { Kebutuhan bahan baku } \\
(\text { Kg) }\end{array}$ & $\begin{array}{l}\text { Biaya bahan baku (Kopi } \\
\text { biji) }\end{array}$ & Rp. 66.000,- \\
$\begin{array}{l}\text { Harga bahan baku } \\
(\mathrm{Rp} / \mathrm{Kg})\end{array}$ & Rp. 22.000,- & Rp. 22.000,- \\
\hline
\end{tabular}

Tabel 1,2,3,4 memperlihatkan bahwa nilai tambah yang menjadi produk bubuk murni per produksi adalah sebesar 2,4 Kg dari pemakaian input sebesar $3 \mathrm{Kg}$. Berdasarkan besaran output dan input bahan baku utama diperoleh nilai faktor konversi sebesar 0,8. Nilai faktor konversi tersebut menunjukkan bahwa dari pengolahan satu kilogram bubuk kopi akan menghasilkan 0,8 kilogram bubuk murni. Tenaga kerja yang digunakan berjumlah 2 orang, dimana jumlah hari kerja dalam satu bulan adalah 
Website : http://agritek.unmermadiun.ac.id/index.php/agritek

26 Hari dengan jam kerja adalah merupakan pembulatan dari 6,66 jam menjadi 7 jam per hari. Nilai koefisien tenaga kerja adalah sebesar 0,67 yang berarti dibutuhkan 0,8 HOK untuk melakukan pengolahan menjadi produk bubuk murni.

\begin{tabular}{llc}
\multicolumn{3}{l}{ Tabel 2. Tenaga kerja pengolahan kopi bubuk dalam satu kali produ } \\
\hline No & \multicolumn{1}{c}{ Uraian } & Jumlah \\
\hline 1 & HOK (untuk satu kali produksi) & 2 \\
2 & $\begin{array}{l}\text { Upah tenaga kerja (Rp/hari } \\
\text { kerja) }\end{array}$ & Rp. 100.000,- \\
\hline
\end{tabular}

Tabel 3. Bahan penunjang yang digunakan untuk satu kali produksi (per minggu)

\begin{tabular}{|c|c|c|c|c|c|}
\hline \multirow[t]{2}{*}{ No } & \multirow[t]{2}{*}{ Uraian } & Volume & \multirow[t]{2}{*}{ Harga satuan } & \multicolumn{2}{|c|}{ Biaya } \\
\hline & & Bulan & & Minggu & Bulan \\
\hline 1 & Kemasan+stiker & $48 \mathrm{Pcs}$ & Rp. 2.500,- & Rp. 30.000,- & Rp. 120.000,- \\
\hline 2 & Listrik & & Rp. $40.000,-$ & Rp. $10.000,-$ & Rp. $40.000,-$ \\
\hline \multirow{5}{*}{ No } & Air & & Rp. $20.000,-$ & Rp. $5.000,-$ & Rp. $20.000,-$ \\
\hline & Total & & & Rp. 45.000,- & Rp. 180.000,- \\
\hline & \multicolumn{5}{|c|}{ Tabel 4. Analisis Nilai Tambah Pengolahan Kopi Bubuk } \\
\hline & \multicolumn{3}{|c|}{ Variabel } & Nilai & Keterangan \\
\hline & \multicolumn{3}{|c|}{ Keluaran (Out put) masukan (In put) dan harga } & & \\
\hline 1 & \multicolumn{3}{|c|}{ Output (kg/periode produksi) } & 2,4 & A \\
\hline 2 & \multicolumn{3}{|l|}{ Input ( $\mathrm{Kg} /$ periode produksi) } & 3,0 & $\mathrm{~B}$ \\
\hline 3 & \multicolumn{3}{|c|}{ Tenaga kerja (HOK/ periode produksi) } & 2,0 & $\mathrm{C}$ \\
\hline 4 & \multicolumn{3}{|c|}{ Faktor konversi } & 0,8 & $\mathrm{D}=\mathrm{A} / \mathrm{B}$ \\
\hline 5 & \multicolumn{3}{|l|}{ Koefisien Tenaga kerja (HOK/kg) } & 0,67 & $\mathrm{E}=\mathrm{C} / \mathrm{B}$ \\
\hline 6 & \multicolumn{3}{|l|}{ Harga output $(\mathrm{Rp} / \mathrm{kg})$} & 90.000 & $\mathrm{~F}$ \\
\hline \multirow[t]{2}{*}{7} & \multicolumn{3}{|l|}{ Upah Tenaga kerja (Rp/HOK) } & 100.000 & $\mathrm{G}$ \\
\hline & \multicolumn{3}{|c|}{ Pendapatan dan Nilai Tambah $(\mathrm{Rp} / 2,4 \mathrm{~kg})$} & & \\
\hline 8 & \multicolumn{3}{|c|}{ Harga bahan baku (Rp/Kg) } & 66.000 & $\mathrm{H}$ \\
\hline 9 & \multicolumn{3}{|l|}{ Harga input lain $(\mathrm{Rp} / \mathrm{kg})$} & 45.000 & I \\
\hline 10 & \multicolumn{3}{|l|}{ Nilai output $(\mathrm{Rp} / \mathrm{kg})$} & 264.000 & $\mathrm{~J}$ \\
\hline 11 & \multicolumn{3}{|l|}{ Nilai tambah (Rp/kg) } & 153.500 & $\mathrm{~K}=\mathrm{J}-\mathrm{H}-\mathrm{I}$ \\
\hline & \multicolumn{3}{|l|}{ Rasio nilai tambah (\%) } & $57,59 \%$ & $\mathrm{~L}=\mathrm{K} / \mathrm{J} * 100 \%$ \\
\hline 12 & \multicolumn{3}{|l|}{ Pendapatan Tenaga kerja (Rp/kg) } & 67.000 & $\mathrm{M}=\mathrm{E}^{*} \mathrm{G}$ \\
\hline & \multicolumn{3}{|l|}{ Pangsa tenaga kerja $(\%)$} & $43,79 \%$ & $\mathrm{~N}=\mathrm{M} / \mathrm{K} * 100 \%$ \\
\hline 13 & \multicolumn{3}{|l|}{ Keuntungan (Rp/kg) } & $86.000,-$ & $\mathrm{O}=\mathrm{K}-\mathrm{M}$ \\
\hline \multicolumn{3}{|c|}{ Tingkat keuntungan $(\%)$} & & $32,57 \%$ & $\mathrm{P}=\mathrm{O} / \mathrm{J} * 100 \%$ \\
\hline \multicolumn{6}{|c|}{ Balas jasa Faktor produksi } \\
\hline \multirow[t]{4}{*}{14} & \multicolumn{3}{|l|}{$\operatorname{Marjin}(\mathrm{Rp} / 2,4 \mathrm{~kg})$} & 198.000 & $\mathrm{Q}=\mathrm{J}-\mathrm{H}$ \\
\hline & \multirow{3}{*}{\multicolumn{2}{|c|}{$\begin{array}{l}\text { a. Tenaga kerja }(\%) \\
\text { b. Modal (sumbangan input lain) }(\%) \\
\text { c. Keuntungan }(\%)\end{array}$}} & & $33,83 \%$ & $\mathrm{R}=\mathrm{M} / \mathrm{Q} * 100 \%$ \\
\hline & & & & $22,72 \%$ & $\mathrm{~S}=\mathrm{I} / \mathrm{Q} * 100 \%$ \\
\hline & & & & $43,43 \%$ & $\mathrm{~T}=\mathrm{O} / \mathrm{Q} * 100 \%$ \\
\hline
\end{tabular}

Nilai tambah yang diperoleh dari pengolahan kopi menjadi produk bubuk murni adalah sebesar Rp.153.500,- Rasio nilai tambah bubuk kopi yang diolah menjadi produk bubuk murni adalah sebesar 57,59 \%, artinya setiap Rp.264.000,- dari nilai output terdapat nilai tambah sebesar Rp.153.500,-. Distribusi nilai tambah terhadap pendapatan tenaga kerja diperoleh dari hasil perkalian antara koefisien tenaga kerja dengan upah rata-rata tenaga kerja. Besarnya pendapatan tenaga kerja yang diperoleh sebesar Rp.67.000,- per 2,4 kilogram bahan baku dengan pangsa tenaga kerja sebesar 43,79\% dari nilai tambah kotor. Nilai ini menunjukkan bahwa setiap Rp.264.000,- dari nilai tambah maka sebesar 33,83\% merupakan bagian untuk tenaga kerja. Pengolahan kopi menjadi produk bubuk murni telah memberikan keuntungan bagi karyawan. Keuntungan yang diperoleh dari kegiatan produksi tersebut sebesar Rp.153.500,- per 2,4 kilogram. Nilai tersebut merupakan nilai tambah bersih karena sudah dikurangi dengan pendapatan tenaga kerja langsung. Tingkat keuntungan pengolahan sebesar 43,43\%. Margin yang diperoleh dari hasil analisis nilai tambah bubuk murni sebesar Rp. 198.000,- dari bahan bahan baku. Besarnya margin akan didistribusikan pada faktor-faktor produksi yang terdiri dari 38,83\% untuk pendapatan tenaga kerja dan $22,72 \%$ untuk sumbangan input yang lainnya, dan untuk keuntungan sebesar 43,43\%.

Noviantari, Hasyim, Rosanti (2015), menyampaikan bahwa rata-rata nilai tambah yang diperoleh dari pengolahan satu kilogram buah kopi menjadi kopi luwak biji Rp 67.123,95, kopi luwak biji menjadi kopi luwak bubuk Rp 78.887,87 dan buah kopi menjadi kopi luwak bubuk Rp 42.666,01. Nilai tersebut menunjukkan bahwa agroindustri kopi luwak tersebut menguntungkan. Selanjutnya Priantara, Mulyani, Satriawan (2016), bahwa dalam proses produksi pengolahan kopi 
Website : http://agritek.unmermadiun.ac.id/index.php/agritek

gelondong merah menjadi kopi Hs, telah menghasilkan nilai tambah sebesar Rp. 9.918 / kg, proses pengolahan kopi Hs menjadi kopi Ose menghasilkan nilai tambah Rp. 40.749 / kg dan untuk pengolahan kopi Ose menjadi kopi bubuk memperoleh nilai tambah sebesar Rp. 118.057 / kg. Nilai tambah yang diperoleh tergolong pada rasio nilai tambah tinggi (diatas $40 \%)$.

\section{IV.KESIMPULAN}

Terdapat lima saluran pemasaran di Kecamatan Wonosalam Kabupaten Jombang. Margin yang diperoleh dari hasil analisis nilai tambah bubuk murni sebesar Rp. 198.000,- dari bahan bahan baku. Besarnya margin akan didistribusikan pada faktor-faktor produksi yang terdiri dari $38,83 \%$ untuk pendapatan tenaga kerja dan $22,72 \%$ untuk sumbangan input yang lainnya, dan untuk keuntungan sebesar $43,43 \%$.

\section{UCAPAN TERIMAKASIH}

Penulis mengucapkan terimakasih kepada petani kopi robusta dan ketua kelompok tani di Kecamatan Wonosalam yang telah memberikan informasi dan izin untuk melaksanakan penelitian, serta terimakasih kepada dosen pembimbing yang telah memberikan saran dan ilmu.

\section{VI.DAFTAR PUSTAKA}

Aklimawati, Lya. 2017. "Value-Added Product on Coffee Marketing in Pasuruan District." Pelita Perkebunan (a Coffee and Cocoa Research Journal) 33(3):211.

BPS. 2019. STATISTIK KOPI INDONESIA 2019. edited by Sub Direktorat Statistik Tanaman Perkebunan. Jakarta: Badan Pusat Statistik.

Desiana, Candra, Dini Rochdiani, and Cecep Pardani. 2017. “Analisis Saluran Pemasaran Biji Kopi Robusta (Suatu Kasus Di Desa Kalijaya Kecamatan Banjarsari Kabupaten Ciamis).” Jurnal Ilmiah Mahasiswa AGROINFO GALUH 3(2):162-73.

Direktorat jenderal Perkebunan. 2019. Statistik Perkebunan Indonesia 2018-2020. edited by D. Gartina and R. L. L. Sukriya. Jakarta: Seketariat Direktorat Jenderal Perkebunan.

Hamdan, Dani, and Aries Sontani. 2018. Coffee Karena Selera Tidak Dapat Diperdebatkan. Jakarta.

Hanafie, Rita. 2010. Pengantar Ekonomi Pertanian. Yogyakarta: CV Andi Offset.

Hayami, Yujiro, Toshihiko Kawagoe, Yoshinori Morooka, and Masjidin Siregar. 1987. Agricultural Marketing and Processing in Upland Java A Perspective From A Sunda Village.

Kotler. 2011. Manajemen Pemasaran Di Indonesia : Analisis, Perencanaan, Implementasi Dan Pengendalian.

Kotler, and Gary Amstrong. 2006. Manajemen Pemasaran.

Marimin, and N. Maghfiroh. 2010. Aplikasi Teknik Pengambilan Keputusan Dalam Manajemen Rantai Pasok. Bogor: IPB Press.

Nazir, M. 2009. Metode Penelitian. Jakarta: Ghalia Indonesia.

Pramasari, Ika Fatmawati, and Yuli Hariyati. 2018. "Value Added and Strategy Development Of Galangal-Coffee Agroindustry." International Journal of Education and Research 6(5):45-56.

Rahardjo, Pudji. 2012. Panduan Budidaya Dan Pengolahan Kopi Arabika Robusta.

Sumarwan, Ujang. n.d. Pemasaran Strategik: Perspektif Perilaku Konsumen Dan Marketing Plan. Bogor: PT Penerbit IPB Press. 